Portland State University

PDXScholar

2-21-1984

\title{
Body Weight Changes Throughout the Menstrual Cycle and Their Effect Upon the Components of Body Composition
}

Lovina M. Query

Portland State University

Follow this and additional works at: https://pdxscholar.library.pdx.edu/open_access_etds

Part of the Health and Physical Education Commons, Medical Sciences Commons, and the Obstetrics and Gynecology Commons

Let us know how access to this document benefits you.

\section{Recommended Citation}

Query, Lovina M., "Body Weight Changes Throughout the Menstrual Cycle and Their Effect Upon the Components of Body Composition" (1984). Dissertations and Theses. Paper 3332.

https://doi.org/10.15760/etd.3312

This Thesis is brought to you for free and open access. It has been accepted for inclusion in Dissertations and Theses by an authorized administrator of PDXScholar. Please contact us if we can make this document more accessible: pdxscholar@pdx.edu. 
AN ABSTRACT OF THE THESIS OF Lovina M. Query for the Master of Science in Teaching in Physical Education presented February 21, 1984.

Title: Body Weight Changes Throughout the Menstrual Cycle and their Effect Upon the Components of Body Composition.

APPROVED BY MEMBERS OF ThE THESIS COMMITTEE:

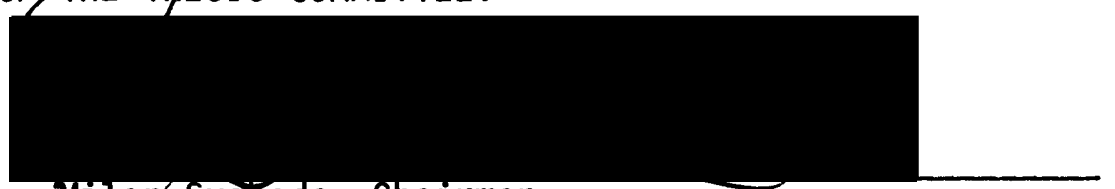

Milapy Svoboda, Chairman

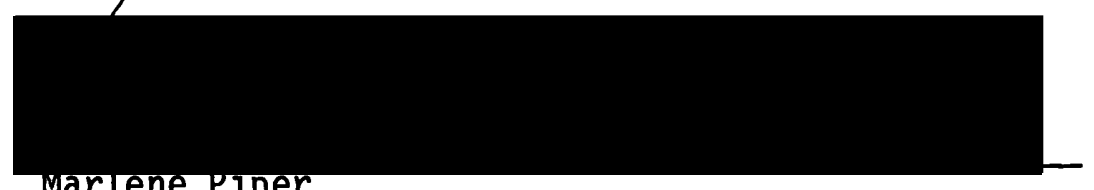

Marrene piper

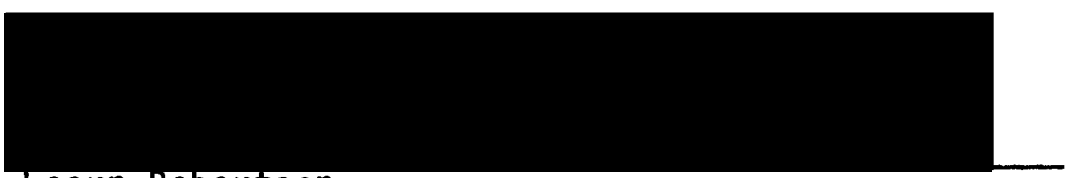

Loarn Robertson

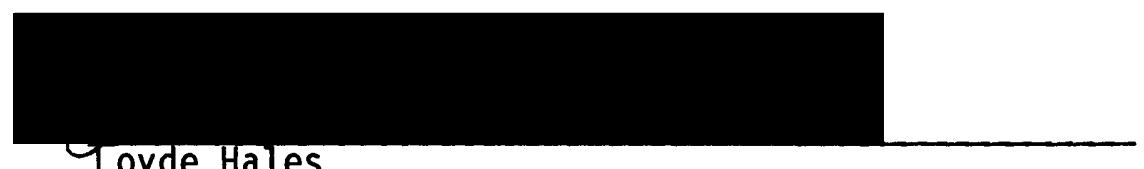

Research has shown that women experience fluctuations in body weight (BW) due to water retention and/or other processes at various times in the menstrual cycle. The purpose of this study is to measure women repeatedly throughout the course of one menstrual cycle and (1) to confirm whether significant fluctuations in weight occur at various times and 
(2) to determine whether there are significant differences in the components of body composition by hydrostatic weighing which are related to any changes in $B W$.

Twenty-six women between 18 and 39 years of age, averaging $51.3 \mathrm{~kg}$. and $22.9 \%$ fat and with normal menstrual function were recruited. They were weighed on land three times per week, beginning with day 1 of their menstrual cycle (first day of flow). Hydrostatic weighing trials were performed under standard conditions on the first day and thereafter on every other land-weight trial. Additional hydrostatic weighing trials were done whenever the subjects gained .5 $\mathrm{kg}$. or more on land, or if a peak or low weight was reached. An overlap weighing was taken at the beginning of the next menstrual cycle to observe whether any net changes had occurred. Residual volume (RV) measurements were taken three times during the cycle, as close as could be predicted to the beginning, middle, and end of the cycle and the average of all measured RV's was used in the calculations of density (D) and percent fat (\%fat).

Although menstrual cycles vary in length from woman to woman, research has shown that ovulation occurs at a relatively constant time of 13 to 15 days prior to flow. Therefore to equalize the cycles around ovulation, raw scores were averaged into five time blocks as follows: counting backwards from the onset of flow, three five-day blocks were formed with the remaining days broken into two halves. A repeated measures ANOVA was used to analyze the blocks of data over time.

Overlap comparisons (with one representing the first measurement 
and two representing the overlap weighing) showed little variation in group means: $B W 1=59.33 \mathrm{~kg}$. vs. $B W 2=59.31 \mathrm{~kg} ; \mathrm{D} 1=1.0468 \mathrm{vs} . \mathrm{D} 2$ $=1.0467$; and $\% f a t(1)=22.869$ vs. $\% f a t(2)=22.869$. Test-retest correlations indicated high reliability $(r=.983$ to $r=.995)$

Repeated measures ANOVA over blocks yielded a significant $F$ ratio for BW. Tukey's HSD test comparing blocks revealed that the block preceding ovulation had significantly lower BW $(59.016 \pm 7.03$ kg.) than the block for the five days prior to menstruation $159.495 \pm$ $6.97 \mathrm{kg.l}$. Similar runs of repeated measures ANOVA for D, \%fat, fat weight and fat-free weight were not significant.

While $D$ and ofat did not show significance when analyzed over blocks, individual variation occurred at every stage of the menstrual cycle for $B W, D$ and \%fat. The total weight change (an individual's high weight minus her low weight) ranged from $2.45 \mathrm{~kg}$. to $.58 \mathrm{~kg}$. with $1.36 \mathrm{~kg}$. being the average total weight change. The \%fat change corresponding to this weight change did not follow any pattern, and in half the subjects, the \%fat was lower at the high weight than at the low weight.

It was concluded that while significant fluctuations in BW occur at certain times in the menstrual cycle, the changes are small and do not result in significant differences in the components of body composition by hydrostatic weighing at these same times. Considerable within-subject variability occurs for all parameters, however, and further research into the mechanisms appears warranted. 
BODY WEIGHT CHANGES THROUGHOUT THE MENSTRUAL CYCLE AND THEIR EFFECT UPON THE COMPONENTS

OF BODY COMPOSITION

by

Lovina M. Query

A thesis submitted in partial fulfillment of the requirements for the degree of

MASTER OF SCIENCE in TEACHING

in

PHYSICAL EDUCATION

Portland State University

1984 
TO THE OFFICE OF GRADUATE STUDIES AND RESEARCH:

The members of the Committee approve the thesis of

Lovina M. Query presented February 21, 1984.

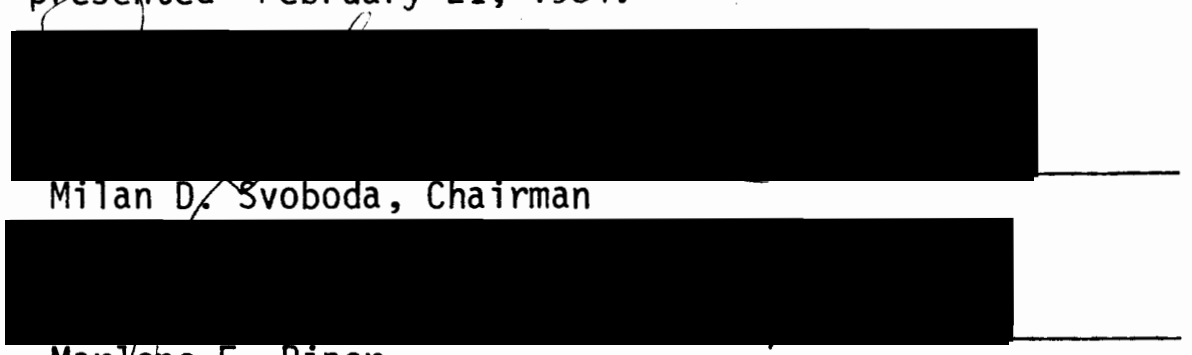

Marvene F, Pjoer

Loarn D. Robertson

APPROVED:

Loyde W. Háles

Jack 5\% Schendel, Dean of the School of Health and Physical Education

Stanley E.-Rauch, Dean of Graduate Studies and Research 


\section{ACKNOWLEDGEMENTS}

This study could not have been accomplished without the help and cooperation of many people. A special thanks to the twenty-six women who so conscientiously adhered to guidlelines of the study and came in to the Exercise Physiology Lab three days a week in spite of holidays, finals, and weather. Without their dedication, this study would not have been possible.

My most special thanks to Dr. Milan Svoboda whose talents as a teacher sparked my interest in Exercise Physiology. I thank him for his expectations of excellence and his advice in my choosing areas of interest to study. Because of his friendship, patience, and insistence upon a policy of non-compromise (even when I resisted), the study is one that will make a contribution in the area of body composition assessment. His example as a scholar and as a human being have given me goals to strive for.

I would also like to thank Dr. Loarn Robertson and Dr. Marlene Piper for serving on my committee. Both of them I admire tremendously as professionals and their careful and critical review of my manuscript greatly improved its content and organization.

My thanks to Dr. Loyde Hales for taking the time to serve on my committee and for his help on the style and form of the manuscript. A special thanks to Dr. Barbara Stewart for sharing her expertise on the statistical problems we encountered. 
Many friends and family contributed to my finishing this project. My appreciation to Dr. Lois Copperman, a friend and scholar, for her advice at every stage of the study. Her insight into research and its special problems plus her editing of my thesis were invaluable. I would also like to thank Virginia Sponsler who offered support in the form of meals, babysitting, and friendship.

To my husband Ron, a special thanks for sharing responsibilities and supporting my return to school. Finally I want to thank my children Nate, Toby, and Crystal for giving meaning to the accomplishment of this goal. 


\section{TABLE OF CONTENTS}

PAGE

ACKNOWLEDGEMENTS .................... i . . . . . . . . .

LIST OF TABLES ..................... . . vii

LIST OF FIGURES .................... . viji

CHAPTER

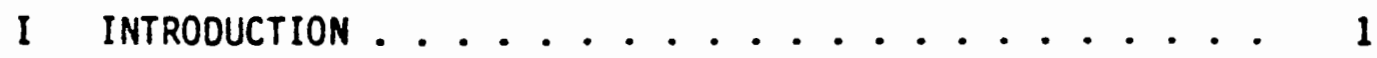

II REVIEM OF RELATED LITERATURE .............. 4

Densitometry ............. 4

Hydration and the Hydrostatic Technique ..... 8

Menstrually Related Weight Changes ........ 9

Densitometry and the Menstrual Cycle ...... 12

Summary ............... . . 12

III STATEMENT OF THE PROBLEM .............. 14

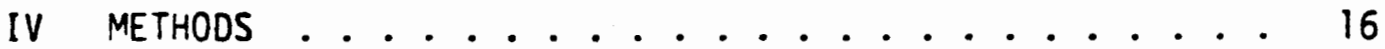

Recruitment Procedures .......... 16

Experimental Design ............ 17

Weighing Procedures ........... 18

Residual Volume Measurements ......... 19

Standardizing the Menstrual Cycle ........ 21

Statistical Analysis ............ 22

V RESULTS AND DISCUSSION ..................... 23

Descriptive Data ............ 23

Analys is of Blocks Over Time ......... 29 
CHAPTER

PAGE

VI CONCLUSION AND IMPLICATIONS FOR FUTURE RESEARCH $\quad$ • • 38

BIBLIOGRAPHY . . . . . . . . . . . . . . . . . . . . . . 39

APPENDIX . . . . . . . . . . . . . . . . . . . . . . 44 


\section{LIST OF TABLES}

TABLE

PAGE

I Descriptive Statistics for Age, Cycle Length, Body Weight, and Body Composition of Subjects ......... 24

II Cycle Lenths and Descriptive Statistics for Body Weight, Density, and Percent Fat of Individual Subjects . . . 25

II Residual Volume of Subjects . . . . . . . . . . 27

IV Overlap Measures for Body Weight and Percent Fat of Subjects................ 28

V Averages of Raw Scores for Time Blocks . . . . . . . 30

VI Summary of Repeated Measures ANOVA for Body Weight . . . 30

VII Summary of Repeated Measures ANOVA for Density . . . . . . 32

VIII Summary of Repeated Measures ANOVA for Percent Fat . . . 32

IX Summary of Repeated Measures ANOVA for Fat Weight . . . 33

$X$ Summary of Repeated Measures ANOVA for Fat-free Weight . . 33

XI High and Low Body Weight and Corresponding Percent Fat Change ............... 35 


\section{LIST OF FIGURES}

FIGURE

PAGE

1. Time Blocks of the Menstrual Cycle ......... 21

2. Averages of $\mathrm{D}, \mathrm{BW}, \% \mathrm{fat}$, FW and FFW Over Time .... 31 


\section{CHAPTER I}

INTRODUCTION

In the last decade, the participation of women in sport and exercise, not only on the high school and collegiate level, but also as a recreational activity, has mushroomed. As the benefits and rewards of physical exercise are experienced, this trend most likely will continue if not increase. In an attempt to answer questions asked by participating women and their trainers, coaches and doctors, research on women athletes has also expanded. One of the more commonly explored themes is to investigate sex differences in the physiological response to exercise and training. Numerous research projects investigating sex differences have been undertaken in recent years. The effect of hormones involved in the menstrual cycle and the higher fat content of women are two examples of sex-linked topics which have been explored. (Jurkowski, Jones, Walker, Younglae and Sutton, 1978, Stevenson, Kolka and Wilkerson, 1982, Hirata, 1966) However, more fundamental questions relating to both of the above topics still remain unanswered. Specifically, the question of menstrually related weight changes and the role, if any, these changes may play in the components of body composition merits exploration.

The assessment of body composition allows one to study the effects of training upon fat-free weight, fat weight, and percent fat. The most widely used methods used for assessing body composition are 
anthropometric techniques and hydrostatic weighing. Anthropometry, in its most common form makes use of skinfold measurements of subcutaneous fat. The obtained measurements are substituted in regression equations which are based upon the hydrostatic weighing technique. Al though more practical for mass testing, such methods are associated with greater error than through body densitometry, the most frequently used method of body composition analysis (Buskirk 1961, Wilmore and Behnke, 1970). of the two techniques of body densitometry (hydrostatic weighing and the volume displacement method), hydrostatic weighing is felt to be more convenient and adaptable to a wide range of experimental conditions (Sinning, 1977).

In the hydrostatic weighing technique, the subject is weighed on dry land and again while submerged. Using "Archimedes" Principle, the density of the body can be determined. The amount of air in the lungs at the time of submersion must be accounted for in order to get an accurate measurement of density. When density is known, the components of body composition can be predicted from equations based upon research on cadavers (Siri, 1961, Brozek, Keyes and Anderson, 1963). Three prediction equations have been developed, based upon the assumption that the densities of the fat free weight and fat weight are constant and additive (Rathbun and Pace, 1954, Siri, 1961, Brozek, et al. 1963).

No physiological process or entity remains constant at all times; this includes body weight even in a person who is not in a state of weight gain or weight 10ss. Such weight fluctuations, whenever and for whatever reason they may occur, must be considered when assessing 
body composition. By definition, changes in body weight can only arise from changes in fat weight, fat free weight, or both. The reliability of the hydrostatic weighing technique has been reported to range between $r=.92$ to $r=.99$ (Katch, Michael and Horvath, 1967, Sinning, 1977, Wilmore, 1983, Lohman, 1981). However, such reliability estimates have been made on male subjects only and over short periods of time. Longitudinal studies of body composition fluctuations in subjects of either sex have received little attention in the literature.

Throughout the course of the menstrual cycle many women gain weight temporarily due to water retention or other mechanisms (Good, 1978, Dalvit, 1981, Thorn, Nelson and Thorn, 1938). Research has shown that variations in hydration do influence the measurement of density by hydrostatic weighing, thus causing variation in computed estimates of percent fat, fat weight, and fat free weight (Girandola, Wiswell and Romero, 1977, Thomas and Etheridge, 1979). The purpose of the present study is to observe body weight fluctuations in women throughout the course of the menstrual cycle and assess their effect on the components of body composition as measured by hydrostatic weighing. 


\section{CHAPTER II}

\section{REVIEW OF RELATED LITERATURE}

In reviewing the literature, the basic assumptions and issues relating to hydrostatic weighing will be presented. Next the research on weight gains or losses due to hydration changes and their effect on body composition assessment by hydrostatic weighting will be discussed. Documentation on weight gains throughout the menstrual cycle will follow and finally the research to date that has looked at the relationship of a possible effect of this weight change on body composition assessment by hydrostatic weighing will be presented.

\section{DENSITOMETRY}

When the relationship between body density (D) and fatness was discovered and the densitometric method was refined, an equation to predict percent fat (\%fat) based upon density needed to be derived in order to estimate one's degree of leanness. Analysis of a limited number of cadavers (Siri, 1961) suggested that certain assumptions were tenable. Different approaches were used in the development of the two formulas which are most widely used today (Siri, 1961, Brozek, et. al., 1963). However, both assumed that the body can be divided essentially into two components: one fat and the other fat free. For purposes of measurement, both formulas are expressed as weights with body weight 
(BW) referring to the weight of the total body, fat weight (FW) referring to the weight attributable to adipose tissue, and fat free weight (FFW) referring to weight attributable to all other tissues. For ease of reference these and other symbols referring to body composition are listed in the Appendix.

To derive prediction equations it was necessary to establish a standard or reference body from which others differ only in the amount of fat. In Siri's formula (see below), the reference body is assumed to be fat-free with a density of $1.1 \mathrm{~g} / \mathrm{ml}$. The density of the fat component is assumed to be $.900 \mathrm{~g} / \mathrm{ml}$. On the other hand, in Brozek's formula (see below), it is assumed that the reference body had a density of 1.064 (or $15.3 \%$ fat) with a density of fat $=.9007 \mathrm{~g} / \mathrm{ml}$. and density of fat-free tissue $=1.1 \mathrm{~g} / \mathrm{ml}$ The formulas are:

$$
\begin{aligned}
& \text { Siri (1961): } F=4.950 / D-4.500 \\
& \text { Brozek (1963): } F=4.570 / D-4.142 \\
& \text { Where } F=\text { percent fat } \\
& \qquad D=\text { density of the body }
\end{aligned}
$$

These two equations agree within $1 \%$ fat for density units between 1.09 and 1.03 , (4\% to $30 \%$ fat) (Lohman, 1981). When \%fat values greater than $30 \%$ are reached, the Siri equation gives increasingly higher values than Brozek (Lohman, 1981). Thus, it appears that except for the very obese, either equation can be used.

The accuracy of estimating body fat using the above two equations depends on how constant the fat and fat-free components are in composition and density. Individuals have been shown to vary in density of their fat- free mass and to vary in the proportion of 
skeleton to fat-free mass according to age, physical activity and race (Lohman, 1981, Bakker and Struikenkamp, 1977, Weredin and Kyle, 1960). Individual variation in the proportion of skeletal weight to FFW has been reported to be $10-23 \%$ (Bakker and Struikenkamp, 1977). Measurements in two subjects with osteosclerosis and osteoporosis resulted in densities of fat-free body of $1.189 \mathrm{~g} / \mathrm{ml}$. and $1.057 \mathrm{~g} / \mathrm{ml}$. respectively (Bakker and Struikenkamp, 1977). Garn found that blacks and whites differ in their skeletal weights by $6-7 \%$, that women have less bone mineral content than men, whites less bone mineral content than blacks, and aged less than the adult population (Garn, 1963). In addition to the above, Garn noted evidence that the mineral content of the fat-free body is not constant, and there is evidence that the water content of the fat-free body also varies considerably (Bakker and Struikenkamp, 1977, Lohman, 1981, Wilmore, 1983). Given such evidence that the underlying assumptions behind densitometry as currently praticed are not true in all persons, the use of body density to estimate body fat can result in an underestimate or overestimate of actual values. With this in mind, it has been suggested that comparisons between individuals should be discouraged, and this method should be used only in regard to changes within an individual (Katch and Katch, 1980). However, despite such evidence, the practice of comparing individuals continues to be widely practiced.

With regard to measuring changes in a single individual's body fat, there are other difficulties with the densitometric method. Studies have shown that tissue changes in weight gain are different than tissue changes in weight loss (Brozek et. al., 1963). The 
density of adipose tissue can vary from $.90-.95 \mathrm{~g} / \mathrm{ml}$. For example, in a very obese person, adipose tissue has a density of $.948 \mathrm{~g} / \mathrm{ml}$. (65\% fat, $14 \%$ water and $22 \%$ cell residue) (Brozek et a1., 1963). Unless either of these conditions of weight changes are of interest, subjects must not be in a state of weight gain or loss.

Another factor crucial to the accurate computation of density is the assessment of the amount of air left in the lungs after maximal exhalation, or the residual volume (RV). Several different methods for measuring RV are commonly used (Wilmore 1969). No systematic attempt to compare all methods and assess their relative accuracy has been found in the literature. However, predictions of RV based on vital capacity measurements are estimated to contribute an error of $1 \%$ fat based on data of male subjects (Wilmore, 1969).

Attempts have been made to estimate the total error associated with application of the hydrostatic weighing technique (Bakker and Struikenkamp, 1977, Lohman, 1981). Errors which result when the density of the fat-free body is assumed not to vary when in fact evidence suggests that it does, is termed biological error (Lohman, 1981). In addition, technical errors of measurement also occur. The total error of measurement is therefore the sum of biological plus technical sources of error. This total error, expressed as a standard error of measurement in $\mathrm{gfat}$ units is estimated by Lohman to be $\pm 3.89 \%$ fat when applying hydrostatic weighing methods to individuals other than adult males (Lohman, 1981). The reliability of hydrostatic weighing has been reported to range between $r=.92$ and $r=.99$ (Katch, Michael and Horvath, 1967, Sinning, 1977, Lohman, 1981, Wilmore, 1983). 
While such values indicate high reliability, the range may be lower for women since these values have been obtained in short periods of time on a test-retest basis and on male subjects. Little research has focused on fluctuations in body composition over time on a longitudinal basis. Only one study has been found which repeatedly measured women using hydrostatic weighing during two successive menstrual cycles (Byrd and Thomas, 1983). Thus, hydrostatic weighing has definite limitations, both due to biological variability of individuals, and to the technical sources of error. Comparisons should not be made between individual's except for an individual concerning his/her own changes in fatness over time. With more concern over the sources of variability, perhaps increased accuracy can be achieved through further research and refinement of techniques (Wilmore, 1983).

HYDRATION AND THE HYDROSTATIC WEIGHING TECHNIQUE

The effects of weight changes due to hydration changes and the effect on $B C$ assessment has been investigated in two different studies. In studying hyperhydration and dehydration in a group of men, Girandola et al. (1977) found significant changes in the \%fat measurements due to variations in hydration. Immediately before ingesting $1.2-2.41$ iters of water and immediately after ingestion, the same measurements were repeated. One week later after another initial set of measurements, subjects entered a sauna at $170^{\circ} \mathrm{F}$ and remained there for 35 minutes and were remeasured. In the hyperhydrated state, there was a $2.4 \%$ increase in body weight (BW), and no appreciable change in RV or 
underwater weight. These changes resulted in a decrease in $D$ causing the predicted \%fat to increase. In the dehydrated state, the opposite occurred. A mean $.98 \mathrm{~kg}$. decrease in BW and no appreciable change in either underwater weight or RV were observed. Density increased and predicted ofat decreased as a result. Comparing the hyperhydrated state to the dehydrated state, there was a mean change of $1.3 \%$ fat which was statistically significant $(p<.01)$. In some individuals, the observed changes were as large or larger than those reported by investigators as the result of physical training thus emphasizing the importance of monitoring hydration levels when using underwater weighing procedures (Girandola, et al., 1977).

In a study by Thomas and Etheridge (1979), eight trained distance runners were weighed on land and via hydrostatic weighing before and after a distance run of eight to twelve miles at a pace of six to six and one-half minutes/mile. The temperature and humidity were $17^{\circ} \mathrm{C}$ and $70 \%$, respectively. Weight loss averaged $1.3 \mathrm{~kg}$. (or $2.1 \%$ of $\mathrm{BW})$ and a $14.6 \%$ decrease in $\%$ fat was observed $(10.1 \%$ to $8.6 \%$ fat $)$. As underwater weight was not significantly affected, it was concluded that the loss in BW was due to loss of water through sweating, again showing that changes in weight due to hydration level may significantly affect body composition assessment. These two studies illustrate the importance of the relationship between normal hydration and the accuracy of the hydrostatic method.

\section{MENSTRUALLY RELATED WEIGHT CHANGES}

Throughout the course of the menstrual cycle, BW may change due 
to a variety of factors including water retention, thirst and/or appetite. However, before reviewing such literature, terminology will be defined and the stages of normal menstrual function will be described. By convention the first day of a menstrual period is counted as the first day of the cycle. Assuming a 28 day cycle, the menstrual period (or flow phase) usually lasts five days and is followed by a pre-ovulatory period known as the follicular or estrogenic phase. Ovulation (when the ovum is released from the follicle), on a 28 day cycle, usually occurs around day 14. This leads the luteal or progestation phase of the cycle which lasts another 14 days, and the next menstrual period begins.

The total length of the cycle may vary considerably with 28 days merely representing an average. When the entire cycle changes in length, the follicular phase is the phase which varies, ovulation marking the end of this phase, while the luteal and flow phases do not. These last two phases are considerably more consistent, the length of the flow phase being 4-5 days and that of the luteal phase averaging 14 days (Lein, 1979, Guyton, 1981, Williams, 1980, Uricchio, 1973). This means that ovulation always occurs at about 14 days before the beginning of the next period, no matter how long an entire cycle may be. For example, in a 25 day cycle, ovulation would occur on approximately day 11, while in a 35 day cycle, ovulation would occur on approximately day 21 .

An increase in the body's tendency to retain water due to unspecified reasons during the luteal phase has been documented by Good (1978). Diet was not controlled in Good's study. However, in a diet 
controlled study, Bruce and Russell (1962) found a significant sudden weight increase at ovulation which returned to normal. A more gradual weight gain over the 4-5 days prior to menstruation was also observed, which was accompanied by a corresponding retention of water and sodium (Bruce and Russe11, 1962). However, in the same study Bruce found that environmental changes in some individuals could influence weight gains more than the menstrual cycle (Bruce and Russe11, 1962). In a study of 50 women with uncontrolled food intake, Thorn et al. (1938) found 24 (or $48 \%$ ) who gained one $\mathrm{kg}$. or more during the 7-10 days prior to menstruation, while 38 (or $76 \%$ ) gained one $\mathrm{kg}$. or more at the time of ovulation. Thorn et al. (1938) observed a retention of sodium, chloride and water corresponding to these weight gains, but al so a striking increase in thirst and appetite.

In studying the relationships between the menstrual cycle and feeding patterns, Dalvit (1981) found that women eat more food per day 10 days after they ovulate than during the ten days before. In primate studies however, relationships between hormones of the menstrual cycle and feeding patterns have been discovered. Progesterone, (the hormone secreted in the luteal phase) has been shown to have an appetite stimulant effect, while estradiol (a hormone secreted primarily in the follicular phase) has been shown to have an appetite suppressing effect (Czaja and Goy, 1975, Blaustein and Wade, 1976, and Hervey and Hervey, 1967). These studies suggest that women do experience weight fluctuations throughout the course of a menstrual cycle. The gains may be due to water gain (due to retention of sodium and chloride), or due to an increase in thirst or appetite or a combination of these. 


\section{DENSITOMETRY AND THE MENSTRUAL CYCLE}

Since the weight changes throughout a menstrual cycle appear to exist, their effect upon body composition assessment warrant investigation. In a recent study, 12 women were assessed via densitometric methods once during the menstrual, follicular, and luteal phases for two consecutive cycles (Byrd and Thomas, 1983). Mean land weight ranged from 55.78 to $56.12 \mathrm{~kg}$., while mean body density ranged only from 1.0453 to $1.0473 \mathrm{~g} / \mathrm{ml}$. The results revealed no significant differences across time ( $P>.05)$ for land weight, body volume, functional residual capacity, body density, or \%fat. However, as pointed out by Byrd and Thomas, with only one measurement per phase, peak weight may not have been detected. The small sample size also makes the probability of a Type II error more likely (i.e. concluding that the body density is not affected when in fact it is).

\section{SUMMARY}

The review of related literature has demonstrated that there are limitations in the methods of predicting fat from density. Studies dealing with the biological sources of error have suggested that the densities of the tissues which make up the fat and fat-free mass may vary due to race, age, sex, physical activity, and/or diet (Lohman 1981, Wilmore 1983, Bakker and Struikenkamp, 1977, Sinning, 1977, Garn, 1963). Technical errors of measurement also occur. (The sum of the biological and technical sources of error give a standard error of 
estimate of $\pm 3.89 \%(\mathrm{fat})$. Al though reliability of hydrostatic weighing is assumed to be high, longitudinal studies of body composition fluctuations in subjects of both sexes has received little attention in the literature. Variation in hydration level has been shown to affect density and thus predicted \%fat (Girandola et al., 1977, Thomas and Etheridge 1979). In women, temporary weight gain during the menstrual cycle may be due to water retention from osmolality changes, changes in eating patterns, or a combination of the two (Thorn, et al., 1938, Dalvit, 1981, Bruce and Russe11, 1962). The question of how these gains would affect prediction of \%fat needs to be studied. One recent study found no significant changes in BW or the components of body composition during the menstrual cycle, but the sample size was small and subjects were only measured at three points in the cycle. Peak weight changes may easily have been missed. Thus, further investigation into the effects of these weight changes upon body composition assessment seems warranted. 
CHAPTER III

\section{STATEMENT OF THE PROBLEM}

The review of literature has shown that both dehydration (due to exercise or heat stress) and hyperhydration (due to fluid ingestion) can influence BW and components of body composition. Since fluid is assumed to be part of FFW, such changes should presumably have no effect on estimates of fat content of the body.

In densitometry, it is assumed that body density varies only because of changes in the amount of fat and not because of variations in the density of the tissues which makeup the fat-free mass. If, for example, the water content of the fat-free mass changes, then the overall density of the body is influenced, and as described above, the effect is that such changes are assumed to occur because of changes in fat content of the body when in this case it is not. The reason why there is such a large standard error associated with densitometry is because some of the basic assumptions which underlie densitometry are not valid at all times. Further research is needed to be able to develop techniques to adjust for variability in measures which are now assumed to be constant.

The review of literature has shown that women experience fluctuations in BW due to water retention and/or other processes at various times in the menstrual cycle. Whether such weight fluctuations contribute to additional error to the existing techniques for measuring 
body composition as they are applied to women has not been thoroughly studied. It is the purpose of this study to measure women repeatedly throughout the course of one menstrual cycle and:

(1) To confirm whether significant fluctuations in weight occur at various times, and

(2) To determine whether there are significant differences in the components of body composition by hydrostatic weighing which are related to any changes in $\mathrm{BW}$.

Chapter IV will be devoted to describing the research methods employed: sampling procedures, methods of measurement, procedures used to standardize the menstrual cycle, and statistical design. The research findings and discussion are presented in Chapter $V$, with the conclusion in Chapter VI. 


\title{
CHAPTER IV
}

\author{
METHODS
}

\section{RECRUITMENT PROCEDURES}

Women with regular menstrual function were recruited via a presentation in classes at Portland State University and Portland Community College, and through posters displayed on community and college bulletin boards. After an initial phone interview, women who satisfied the requirements and who were willing to adhere to the stated guidelines were accepted. Requirements included that the subjects had not used oral contraceptives or intrauterine devices within the past six months (el Mahgoub, 1980). Subjects were asked not to ingest highly salted foods and/or simple sugars 24 hours prior to each weighing (BW), as such foods cause fluid retention (Williams, 1980). To establish a baseline and to control for hydration changes, the women were required to refrain from engaging in any regularly scheduled physical activity in excess of one and one-half hours per week. Most subjects remained well below these limits of exercise. Informed consent was obtained from each subject in accordance with guidelines set by the Human Subjects Research Review Committee at Portland State University.

Three subjects exhibited fear of water on the first weighing and 
withdrew voluntarily from the study. Another was dropped due to illness, and another due to a fracture which required a cast. One subject violated the limit of weekly physical activity and was dropped from the study. Thus, a total of twenty-six female subjects participated in and completed the study.

\section{EXPERIMENTAL DESIGN}

Subjects began the study on a day which was a close as possible to day 1 of their menstrual cycle (first day of flow); thereafter they were weighed three times per week, at the same time of day throughout one cycle. Subjects were asked to void before being weighed. Underwater weighing weight was determined on the first day and thereafter every other time that the subject was weighed on land. The decision to underwater weigh on alternate days was made because of anticipated difficulty in recruiting subjects who would comply with more frequent underwater weighings.

Additional underwater weighing measurements were made if the following conditions occurred: (1) a subject gained $.5 \mathrm{~kg}$. or more compared to the previous weighing, or (2) if a high or a low weight occurred (in comparison to the previous weighings).

An overlap weighing on land and underwater was taken at the beginning of the next menstrual cycle on the same day that the first weighing was obtained. The overlap weighing was done to observe whether any net changes had occurred during the course of the cycle. A11 subjects were tested in the Exercise Physiology Laboratory at 
Portland State University.

WEIGHING PROCEDURES

Before every weighing, each student filled out a questionnaire concerning changes in eating patterns and/or lifestyle that could affect weight. Subjects were weighed on a Homs Balance Beam Scale accurate to \pm 50 grams. Underwater weights were in a 500 gallon tank using a Chatillon nine kilogram. scale with 10 gram divisions. When underwater weight was needed, subjects were first instructed to remove all air bubbles from bathing suits and hair. On the first weighing, standard procedures were followed where the subject was required to make at least ten trials. The mean of the three highest weights within \pm 50 grams was used as the subjects' score, since this is within the limits of accuracy of the measurement (Sinning, 1977). On the second underwater weighing trial, at least seven trials were required until three weighings within the above mentioned limits of accuracy were obtained. On subsequent weighings, trials were terminated when three similar weighings or ten trials were achieved. In converting density to percent fat, Siri's formula was used:

$$
\text { \%fat }=(4.95 / D)-4.50
$$

Following the recommendation of $\operatorname{Novak}(1974), .1 \mathrm{~L}$. was added to the RV to account for gastrointestinal gases so that the equation of Goldman and Buskirk (1961) was modified as follows: 


$$
D=\frac{M a}{M a-M w-(R V+.1)}
$$

Dw

Where $\mathrm{Ma}=1$ and weight of subject in $\mathrm{kg}$.

$$
\begin{aligned}
& M w=\text { net underwater weight of subject in } \mathrm{kg} \text {. } \\
& \text { DW = density of water at temperature at time of weighing } \\
& \mathrm{RV}=\text { residual volume in liters }
\end{aligned}
$$

\section{RESIDUAL VOLUME MEASUREMENTS}

RV measurements were taken three times during the cycle as close as could be predicted to the beginning, middle, and end of the cycle. Some exceptions to the above are discussed in a later section. Two RV trials were taken at each testing period and averaged. In all calculations of $D$, the average of all RV measurements taken on a subject was used to remove the influence of changes in RV on calculations involving the components of body composition. RV measurements were taken outside the water, using the revised 0xygen Dilution Method (Wilmore, Vodak, Parr, Girandola, and Billing, 1980).

In this method, a five liter rubber rebreathing bag is filled with 3.987 liters of $100 \%$ oxygen as determined by measurement with a standard two-way syringe. The bag was flushed three times with oxygen to insure that no contamination with room air occurred. The bag was attached to a "T" shaped two-way valve with a standard mouthpiece attached to the base of the " $T$ " valve. The valve could open to either room air or the bag. A nose clip was secured firmly on the subject's 
nose and the mouth properly placed around the mouthpiece with the "T" valve open to room air. The subject was instructed to breath a few breaths for familiarity, then to exhale completely and to indicate to the tester when maximal exhalation was attained. At this point, the stopcock was switched to allow the subject to breath from the bag. The subject was instructed to take 5-7 breaths at the rate of one breath/two seconds. Following these breaths, another maximal exhalation into the bag was made, at which time the " $T$ " valve was turned, closing off the bag with the subject again breathing room air.

The logic of the above method is that the only nitrogen in the bag comes from the RV. Therefore from the percent nitrogen, one can calculate the size of the RV. The percent nitrogen in the bag was predicted by analyzing for $\% 02$ and \%CO2 as follows: \%N2 $=100-(\% \mathrm{CO2}+$ q02).

The RV is calculated as follows:

$$
R V=\frac{V 02 \times b}{80.0-(b+0.2)} \text { or } \quad \frac{V 02 \times b}{79.8-b}
$$

Where $b=$ percent nitrogen in the mixed bag

v02 = volume of oxygen in the bag in the beginning of the procedure plus tip space of mouthpiece.

$80.0=$ assumed percent nitrogen in the alveolar air at the beginning of the test

$(b+.2)=$ percentage of nitrogen in the alveolar air during the

last maximal breath. (Assumed to be $0.2 \%$ higher than the equilibrium percentage.

RV under ambient conditions was converted to body, temperature, 
pressure, saturated (BTPS) units using standard procedures. After converting to BTPS, the dead space from the mouthpiece was substracted to provide a net estimate of RV.

STANDARDIZING THE MENSTRUAL CYCLE

Evidence suggest that when the length of the menstrual cycle differs from individual to individual, the length of the luteal phase is relatively constant while the length of the follicular phase varies. Therefore the days of the menstrual cycle were numbered backwards from the onset of menstruation. (i.e. day 1 is the day before menstruation, day 2 is two days before menstruation, etc.). Thus, in a typical 28 day cycle, days 1-14 would be the luteal phase and days 15-23 the follicular phase, with days 24-28 the menstrual or flow days.

To equalize cycles around ovulation, which was predicted to occur between day 13-15 (Guyton, 1981), measurements during the luteal phase were grouped into three, five day blocks as follows: day 1-5 (Block E); 6-10 (Block D); and 11-15 (Block $C$ ). The remaining measurements were broken into two halves (Blocks $B$ and $A$ ). All raw scores within blocks were then averaged. Each subjects' raw scores were thus grouped into five blocks (three luteal plus two additional) so that subjects with cycles of differing length could be compared at equivalent time periods in their respective cycles (See Fig. 1). 


\begin{tabular}{|c|c|c|c|c|}
\hline \multicolumn{4}{|c|}{ Time Blocks } & C \\
\hline A & B & D & D \\
\hline $\begin{array}{c}\text { Half of the } \\
\text { remaining } \\
\text { scores }\end{array}$ & $\begin{array}{c}\text { Half of the } \\
\text { remaining } \\
\text { scores }\end{array}$ & Days 11-15 & Days 6-10 & Days 1-5 \\
\hline Flow and Follicular Phases & Luteal Phase & \\
\hline
\end{tabular}

\section{Ovulation}

Figure 1: Time blocks of the menstrual cycle

For example, for a subject with a 35 day cycle, weights were averaged in the following blocks of days: 1-5, 6-10,11-15, 16-25, 26-35. For another subject with a 24 day cycle, the blocks were days $1-5,6-10$, $11-15,16-19,20-24$.

STATISTICAL ANALYSIS

A repeated measures ANOVA (Nie and HuII, 1981) was used to analyze the blocks of data over time. The level of significance was set at .05 . When a significant $F$ ratio was obtained, Tukey's test of honest significant difference (HSD) was used to determine which pairs of blocks differed from each other (Kirk, 1969).

A test-retest correlation was computed using data from the overlap weighing and the first trial to determine reliability under equivalent physiological conditions. 
CHAPTER $V$

RESULTS AND DISCUSSION

The results and discussion will be presented in three parts. First the descriptive and control data will be presented and discussed. Second, the results and discussion of the statistical analysis of the blocks over time will be presented. Third, individual variability throughout the menstrual cycle will be discussed.

\section{DESCRIPTIVE DATA}

In Table I, descriptive statistics for the sample are presented. Twenty-six subjects ranged from 18 to 39 years; the mean age was slightly younger than the average of PSU women students which is 28.5 years. With the average BW of $51.3 \mathrm{~kg}$. (130 lbs.), the sample was leaner (at $22.9 \% \mathrm{fat}$ ) than the $26 \%$ fat reported for sedentary women (Katch and McCardle, 1973), yet fatter than the 13\% found for highly trained athletes (Hirata, 1966). Mean cycle length (28.58 days) was higher than the 28 days considered typical. (Guyton, 1981).

Table II shows individual mean scores for cycle length, BW, density and \%fat. Cycle lengths varied from 24 to 44 days, causing the number of land weights to range from 11 to 19 per subject and the number of underwater measures to range from 6 to 10 per subject. A 
TABLE I

DESCRIPTIVE STATISTICS FOR AGE, CYCLE LENGTH, BODY WEIGHT, AND BODY COMPOSITION OF SUBJECTS

\begin{tabular}{|lccr|}
\hline \multicolumn{1}{|c}{ Variable } & M & \multicolumn{1}{c|}{ SD } & \multicolumn{1}{c|}{ SE } \\
\hline Age (years) & 27.15 & 6.297 & 1.295 \\
Cycle Length (days) & 28.58 & 4.350 & .870 \\
Body Weight (kg.) & 59.301 & 6.901 & 1.380 \\
Body Density (kg/L) & 1.0467 & .0120 & .0024 \\
Percent Fat & 22.966 & 5.424 & 1.085 \\
Fat Weight (kg.) & 13.790 & 4.308 & .862 \\
Fat-free Weight (kg.) & 45.571 & 4.690 & .938 \\
No. of BW Measures & 12.7 & 1.765 & .353 \\
No. of Underwater & & & .223 \\
\hline
\end{tabular}




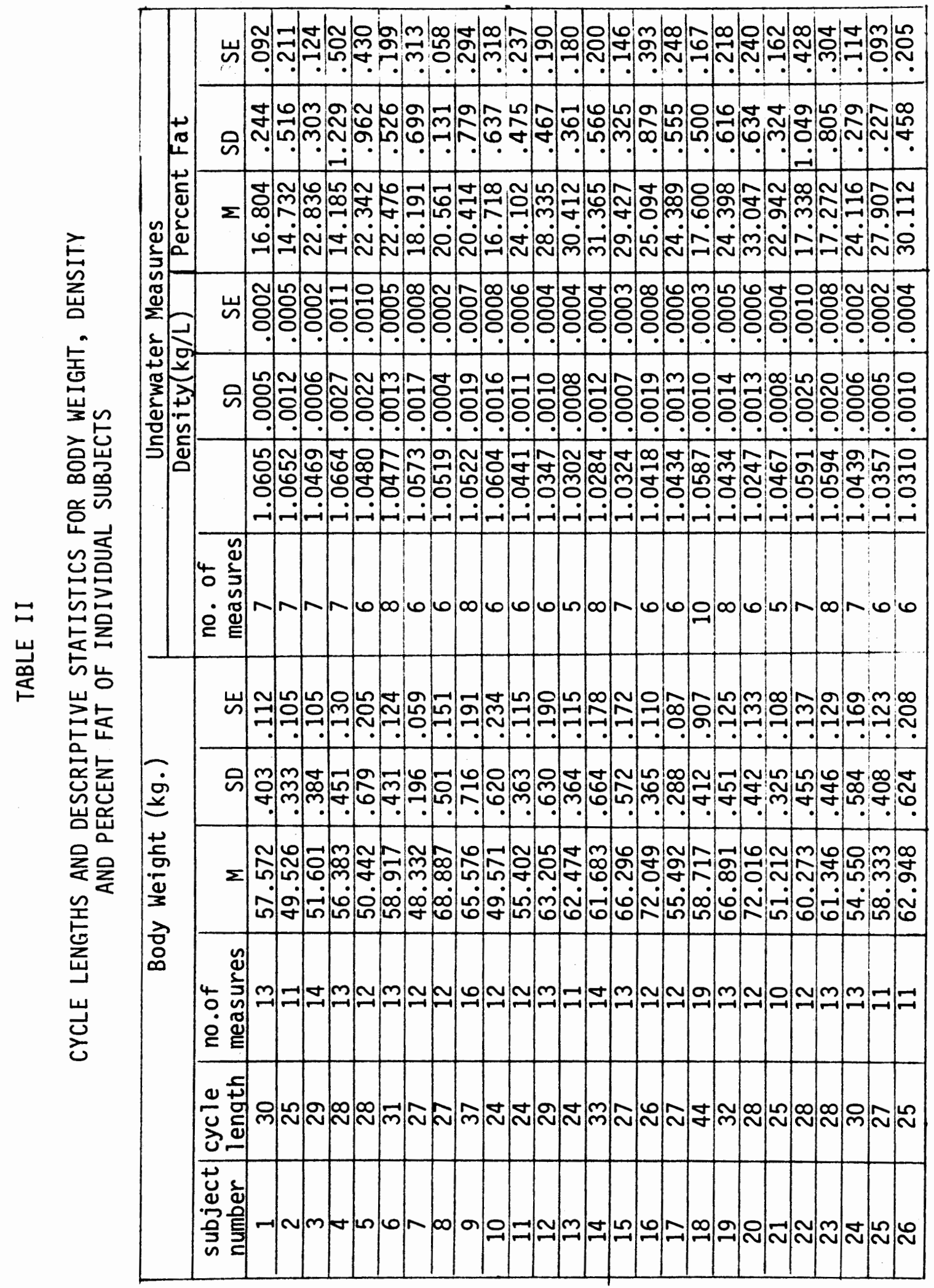


total of 200 underwater weights and 356 land weights were administered. Questionnaires affirmed that exercise and food intake guidelines were adhered to. Standard errors indicated that some subjects remained quite constant, while others fluctuated considerably. In the latter cases, there did not appear to be a consistent relationship between large fluctuations in ofat and similarily large fluctuations in BW.

Residual volumes of all subjects are given in Table III. While RV was measured at three times throughout the cycle (and each measure included a test - retest), equipment breakdown necessitated some RV's to be measured after the study was completed. Since changes in RV can influence the components of body composition, the decision was made to average all RV's using only those taken during the menstrual cycle in question. As a result, average RV's were based on fewer measures for ten of the subjects as indicated in the Table III.

Data from the first day of measurement and that taken on the same day of the next menstrual cycle ("overlap weighing") is presented in Table IV. Included are test-retest correlations for BW, D and \%fat. Overall means showed little variation $(B W 1=59.33 \mathrm{~kg}$. vs. BW2 $=59.31$ kg.; $D 1=1.0468$ vs. $D 2=1.0467$ and \%fat $(1)=22.869$ vs. \%fat $(2)=$ 22.943). The assumption that none of the subjects was in a state of weight gain or weight loss may not be true in every case; however, the group means of the first and last weighings (overlap) indicate that there was no net change in weight within the group as a whole. Test-retest correlations varied between $r=.983$ to .995 indicating very high reliability. 
TABLE III

RESIDUAL VOLUME OF SUBJECTS*

\begin{tabular}{|c|c|l|l|}
\hline $\begin{array}{c}\text { Subject } \\
\text { number }\end{array}$ & RV (L.) & SD & SE \\
\hline 1 & $2.007 \mathrm{a}$ & .141 & .081 \\
\hline 2 & $1.268 \mathrm{a}$ & .074 & .043 \\
\hline 3 & 1.109 & .200 & .089 \\
\hline 4 & $1.531 \mathrm{a}$ & .186 & .107 \\
\hline 5 & $1.202 \mathrm{~b}$ & .115 & .115 \\
\hline 6 & $1.522 \mathrm{a}$ & .060 & .035 \\
\hline 7 & $1.357 \mathrm{a}$ & .193 & .111 \\
\hline 8 & $1.104 \mathrm{a}$ & .191 & .085 \\
\hline 9 & 1.394 & .119 & .049 \\
\hline 10 & $1.222 \mathrm{~b}$ & .130 & .130 \\
\hline 11 & $1.515 \mathrm{a}$ & .303 & .175 \\
\hline 12 & 1.468 & .171 & .077 \\
\hline 13 & .851 & .089 & .039 \\
\hline 14 & $1.098 \mathrm{a}$ & .055 & .032 \\
\hline 15 & $1.271 \mathrm{a}$ & .067 & .039 \\
\hline 16 & $1.678 \mathrm{a}$ & .199 & .115 \\
\hline 17 & 1.455 & .367 & .164 \\
\hline 18 & 1.435 & .091 & .041 \\
\hline 19 & 1.102 & .063 & .028 \\
\hline 20 & 1.365 & .179 & .080 \\
\hline 21 & 1.612 & .215 & .096 \\
\hline 22 & 1.380 & .127 & .057 \\
\hline 23 & 1.438 & .217 & .097 \\
\hline 24 & $1.322 \mathrm{c}$ & .227 & .086 \\
\hline 25 & 1.029 & .128 & .057 \\
\hline 26 & 1.003 & .074 & .033 \\
\hline & & & \\
\hline
\end{tabular}

* Three RV's per subject with the following exceptions:
a. 2 RV trials
b. 1 RV trial
c. 4 RV trials 
TABLE IV

OVERLAP MEASURES FOR BODY WEIGHT AND PERCENT FAT OF SUBJECTS

\begin{tabular}{|c|c|c|c|c|c|c|}
\hline \multirow{2}{*}{$\begin{array}{c}\text { subject } \\
\text { no. }\end{array}$} & \multicolumn{2}{|c|}{ Body Weight $(\mathrm{kg})}$. & \multicolumn{2}{|c|}{ Density $(\mathrm{kg} / \mathrm{L})$} & \multicolumn{2}{|c|}{ Percent Fat } \\
\hline & BW1 & BW2 & D1 & $\mathrm{D} 2$ & $\%$ fat (1) & $\%$ fat (2) \\
\hline 1 & 57.97 & 57.98 & 1.0612 & 1.0608 & 16.448 & 16.624 \\
\hline 2 & 49.09 & 48.87 & 1.0640 & 1.0668 & 15.210 & 13.987 \\
\hline 3 & 52.25 & 51.50 & 1.0474 & 1.0463 & 22.599 & 23.075 \\
\hline 4 & 56.63 & 57.42 & 1.0672 & 1.0674 & 13.849 & 13.744 \\
\hline 5 & 50.70 & 50.08 & 1.0488 & 1.0486 & 21.948 & 22.042 \\
\hline 6 & 58.96 & 59.96 & 1.0487 & 1,0484 & 22.017 & 22.158 \\
\hline 7 & 48.28 & 48.44 & 1.0587 & 1.0547 & 17.575 & 19.330 \\
\hline 8 & 68.68 & 68.49 & 1.0515 & 1.0517 & 20.760 & 20.666 \\
\hline 9 & 64.43 & 65.37 & 1.05 & 1.0529 & 20.089 & 20.146 \\
\hline 10 & 51.00 & 49.22 & 1.0614 & 1.0583 & 16.359 & 17.737 \\
\hline 11 & 55.68 & 54.82 & 1.0455 & 1.0440 & 23.447 & 24.157 \\
\hline 12 & 62.86 & 62.20 & 1.0352 & 1.0354 & 28.176 & 28.084 \\
\hline 13 & 62.30 & 62.01 & 1.0311 & 1.0299 & 30.062 & 30.613 \\
\hline 14 & 61.77 & 62.60 & 1.0310 & 1.0272 & 30.114 & 31.870 \\
\hline 15 & 66.25 & 66.63 & 1.0317 & 1.0324 & 29.779 & 29.460 \\
\hline 16 & 72.00 & 71.88 & 1.0422 & 1.0441 & 24.975 & 24.092 \\
\hline 17 & 55.85 & 55.85 & 1.0449 & 1.0427 & 23.710 & 24.724 \\
\hline 18 & 59.40 & 59.34 & 1.0567 & 1.0589 & 18.454 & 17.463 \\
\hline 19 & 67.29 & 66.58 & 1.0410 & 1.0434 & 25.506 & 24.391 \\
\hline 20 & 72.20 & 72.17 & 1.0248 & 1,0242 & 33.041 & 33.313 \\
\hline 21 & 51.48 & 51.41 & 1.0461 & 1.0469 & 23.168 & 22.811 \\
\hline 22 & 60.58 & 60.51 & 1.0543 & 1.0612 & 19.492 & 16.448 \\
\hline 23 & 61.20 & 61.19 & 1.0606 & 1.0586 & 16.720 & 17.610 \\
\hline 24 & 55.24 & 55.15 & 1.0440 & 1.0436 & 24.122 & 24.307 \\
\hline 25 & 58.49 & 59.13 & 1.0362 & 1.0362 & 27.720 & 27.712 \\
\hline 26 & 62.04 & 63.43 & 1.0328 & 1.0314 & 29.262 & 29.952 \\
\hline$M$ & 59.33 & 59.31 & 1.0468 & 1.0466 & 22.869 & 22.943 \\
\hline SE & 1.34 & 1.38 & .0023 & .0025 & 1.055 & 1.100 \\
\hline$r^{\star}$ & & 95 & & 83 & & \\
\hline
\end{tabular}


ANALYSIS OF BLOCKS OVER TIME

In Table $V$ and Fig. 2, BW, density, qfat, FW and FFW are shown in blocks. (See Methods, page 21, for description of how data was grouped into blocks.) Repeated measures ANOVA of BW over blocks resulted in a significant $F$ ratio (Table VI). The Tukey HSD test indicated that the only pairwise comparison which achieved significance was Block B vs. Block $E$. As can be seen in Figure 2, BW was lowest in Block $B$, or the second half of the follicular phase, and highest in Block $E$, or the 5 days preceeding menstruation. This is consistent with the findings of others (Bruce and Russe11, 1962, Robinson, 1965, and Thorn et al., 1938). Successive runs of repeated measures ANOVA over blocks for D, \%fat, FW and FFW were not significant (Tables VII, VIII, IX and $X$, respectively).

The lack of any apparent relationship between gain and/or loss of BW and density (and hence the components of body composition) is surprising. The influence of small environmental changes on weight must not be overlooked. Bruce and Russell (1962) found premenstrual weight gains were overshadowed by greater fluctuation in weight due to minor environmental changes. In subjects kept on a fixed food intake, however, he was able to isolate weight changes due only to the menstrual cycle.

In the present study, environmental influences such as variability in diet and activity were controlled only through each subject's own willingness to adhere to the research guidelines given to her. The influence of "salty" foods and "sugars" can last for as long 
TABLE $V$

AVERAGES OF RAW SCORES FOR TIME BLOCKS

\begin{tabular}{|lccccc|}
\hline variable & A & B & C & D & E \\
\hline Body Weight $(\mathrm{kg.})$ & 59.162 & $59.016^{\star}$ & 59.313 & 59.262 & $59.495^{\star}$ \\
Density $(\mathrm{kg./L})$ & 1.0471 & 1.0469 & 1.0464 & 1.0465 & 1.0469 \\
Percent Fat & 22.818 & 22.924 & 23.110 & 23.065 & 22.933 \\
Fat Weight $(\mathrm{kg.})$ & 13.680 & 13.707 & 13.891 & 13.840 & 13.833 \\
Fat-free Weight $(\mathrm{kg})$ & 45.531 & 45.296 & 45.384 & 45.422 & 45.660 \\
& Follicular Phase & Luteal Phase & \\
& & & &
\end{tabular}

* significant at $p<.01$

\section{TABLE VI}

SUMMARY OF REPEATED MEASURES ANOVA FOR BODY WEIGHT

\begin{tabular}{|lrrrrr|}
\hline Source & \multicolumn{1}{c}{ SS } & df & MS & $F$ & $p$ \\
\hline Between Subjects & 5991.59 & 25 & 239.6636 & & \\
Within Subjects & 24.85 & 104 & .2484 & & \\
Time & 3.29 & 4 & .8225 & 3.65 & .008 \\
Time by Subject & 22.55 & 100 & .2255 & & \\
Total & 6017.44 & 129 & & & \\
\hline
\end{tabular}




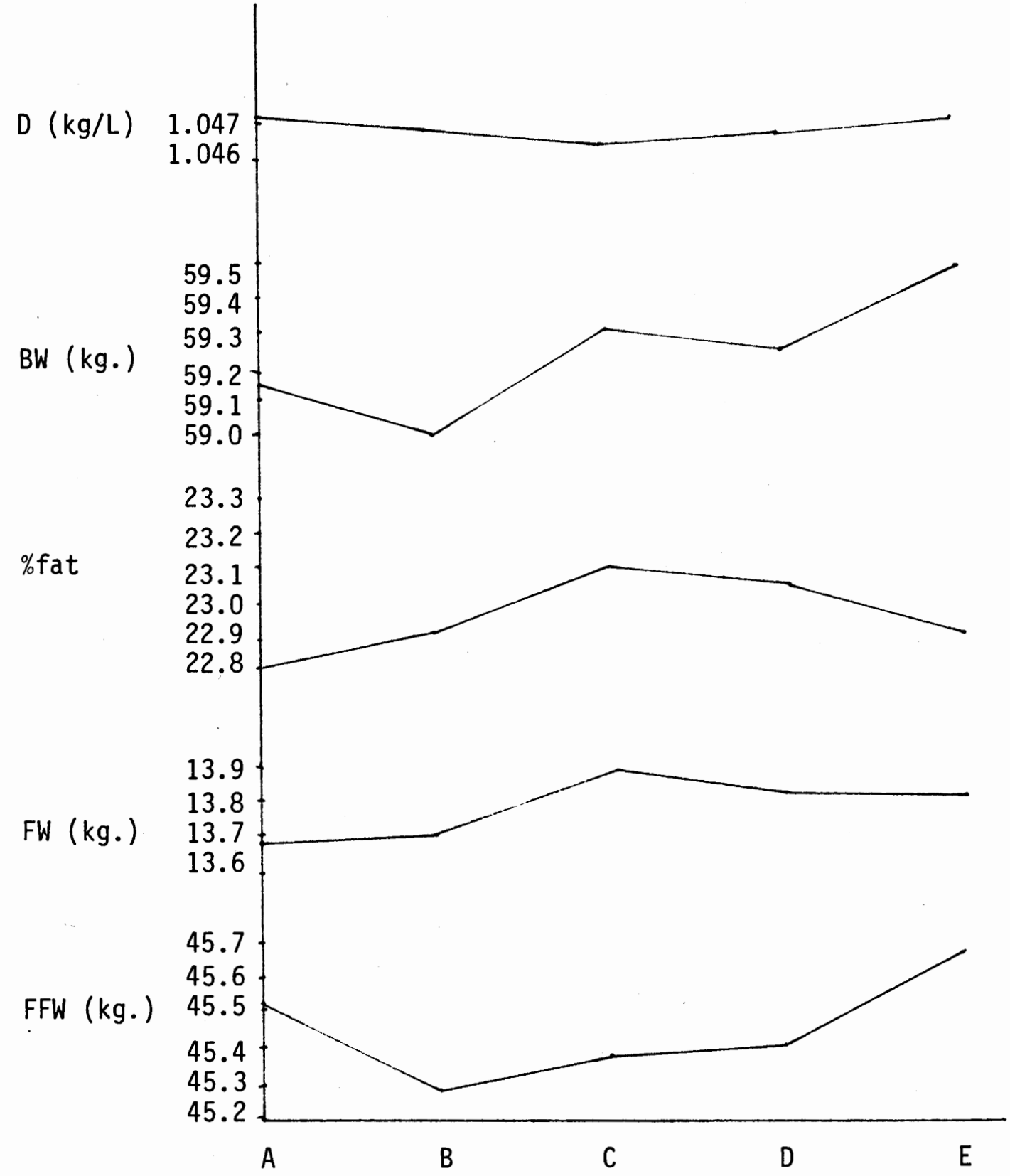

Time Blocks

Figure 2: Averages of D, BW, \%fat, FW and FFW Over Time 


\section{TABLE VII}

SUMMARY OF REPEATED MEASURES ANOVA FOR DENSITY

\begin{tabular}{|lrrrrr|}
\hline Source & \multicolumn{1}{c}{ SS } & df & MS & $F$ & $p$ \\
\hline Between Subjects & .01799 & 25 & .0007196 & & \\
Within Subjects & .00019 & 104 & .0000018 & & \\
Time & .00001 & 4 & .0000025 & 1.39 & .243 \\
Time by Subject & .00018 & 100 & .0000018 & & \\
Total & .01819 & 129 & & & \\
\hline
\end{tabular}

\section{TABLE VIII}

SUMMARY OF REPEATED MEASURES ANOVA FOR PERCENT FAT

\begin{tabular}{|lrrrrr|}
\hline Source & \multicolumn{1}{c}{ SS } & df & MS & $F$ & $p$ \\
\hline Between Subjects & 3671.16 & 25 & 146.846 & & \\
Within Subjects & 35.22 & 104 & .339 & & \\
Time & 1.44 & 4 & .359 & 1.06 & .379 \\
Time by Subject & 33.78 & 100 & .338 & & \\
Total & 3706.37 & 129 & & & \\
\hline
\end{tabular}


TABLE IX

SUMMARY OF REPEATED MEASURES ANOVA FOR FAT WEIGHT

\begin{tabular}{|lrrrrr|}
\hline Source & \multicolumn{1}{c}{ SS } & df & MS & F & P \\
\hline Between Subjects & 2318.67 & 25 & 92.7467 & & \\
Within Subjects & 15.12 & 104 & .1454 & & \\
Time & .87 & 4 & .2170 & 1.521 & .202 \\
Time by Subjects & 14.26 & 100 & .1426 & & \\
Total & 2333.79 & & & & \\
\hline
\end{tabular}

TABLE $X$

SUMMARY OF REPEATED MEASURES ANOVA FOR

FAT-FREE WEIGHT

\begin{tabular}{|lrrrrr|}
\hline Source & \multicolumn{1}{c}{ SS } & df & MS & F & p \\
\hline Between Subjects & 2724.97 & 25 & 109.00 & & \\
Within Subjects & 26.19 & 104 & .25 & & \\
Time & 2.06 & 4 & .51 & 2.13 & .083 \\
Time by Subject & 24.13 & 100 & .24 & & \\
Total & 2751.16 & 129 & & & \\
\hline
\end{tabular}


24 hours. (Williams 1980). Some subjects admitted to having a craving for "salt" or "sugars" at various times and the effects of such dietary (or other environmental) influences may have contributed to greater within-subject variability, thereby masking any underlying changes which may have occurred due to menstrual function. However, it appears from the present data that, on the average, menstrually related weight changes are not of sufficient magnitude to result in significantly different estimates of qfat and other components of body composition at different times in the menstrual cycle.

The need for longitudinal research into these processes can be illustrated by looking further into the variability of these subjects. Although during Block $E$ mean $B W$ was found to be significantly higher than mean $B W$ in $B l o c k B$, individual high (and low) weights did not always follow this trend. This is shown in Table XI, where high BW and low BW for all subjects are listed together with the day of the cycle on which they occurred. This illustrates that while the sample as a whole did show a pattern relating to menstrual cycle over time, peak weights occurred at different times for different subjects. Also in Table XI, the largest weight change occurring throughout the cycle is listed along with the corresponding change in \%fat on those days. As is evident, changes in \%fat did not follow any consistent pattern. Note that a positive score for a change in \%fat means that estimated \%fat increased as $B W$ increased while a negative score means that estimated \%fat decreased when BW increased. Further investigation is warranted to explore the causes of such variability. Such research would be of particular interest in studies which explore the 
TABLE XI

HIGH AND LOW BODY WEIGHT AND CORRESPONDING PERCENT FAT CHANGE

\begin{tabular}{|c|c|c|c|c|c|c|}
\hline $\begin{array}{c}\text { Subject } \\
\text { no. }\end{array}$ & $\begin{array}{c}\text { high } \\
\text { BW(kg.) }\end{array}$ & $\begin{array}{l}\text { day of } \\
\text { cycle* }\end{array}$ & $\begin{array}{c}\text { low } \\
B W(\mathrm{~kg} .)\end{array}$ & $\begin{array}{l}\text { day of } \\
\text { cycle }\end{array}$ & $\begin{array}{c}\text { BW*ᄎ } \\
\text { change }(k g)\end{array}$ & 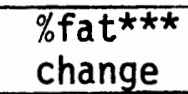 \\
\hline 1 & 57.97 & $5(30)$ & 56.96 & $28(30)$ & 1.01 & -.257 \\
\hline 2 & 50.04 & $24(25)$ & 49.09 & $1(25)$ & .95 & -.229 \\
\hline 3 & 52.25 & $26(29)$ & 51.19 & $13(29)$ & 1.06 & -.230 \\
\hline 4 & 56.71 & $28(28)$ & 55.84 & $10(28)$ & .87 & -3.954 \\
\hline 5 & 51.53 & $27(28)$ & 49.56 & $11(28)$ & 1.97 & .120 \\
\hline 6 & 59.55 & $29(31)$ & 58.51 & $15(31)$ & 1.04 & -.821 \\
\hline 7 & 48.66 & $12(27)$ & 47.91 & $25(27)$ & .75 & -.275 \\
\hline 8 & 69.67 & $20(27)$ & 68.39 & $8(27)$ & 1.28 & .110 \\
\hline 9 & 66.88 & $25(37)$ & 64.43 & $4(37)$ & 2.45 & .724 \\
\hline 10 & 51.00 & $4(24)$ & 49.05 & $8(24)$ & 1.95 & .523 \\
\hline 11 & 55.74 & $9(24)$ & 54.81 & $22(24)$ & .93 & -.998 \\
\hline 12 & 63.95 & $27(29)$ & 62.55 & $18(29)$ & 1.40 & .521 \\
\hline 13 & 63.19 & $21(24)$ & 61.91 & $16(24)$ & 1.28 & -1.022 \\
\hline 14 & 62.70 & $1(33)$ & 60.39 & $13(33)$ & 2.31 & -.098 \\
\hline 15 & 66.63 & $17(27)$ & 65.25 & $3(27)$ & 1.38 & .414 \\
\hline 16 & 72.59 & $12(26)$ & 71.29 & $26(26)$ & 1.30 & 2.736 \\
\hline 17 & 56.00 & $6(27)$ & 55.05 & $20(27)$ & .95 & -1.179 \\
\hline 18 & 59.40 & $1 ; 38(44)$ & 58.02 & $10(44)$ & 1.38 & $1.91 ; .78$ \\
\hline 19 & 67.46 & $6(32)$ & 66.10 & $27(32)$ & 1.36 & 1.058 \\
\hline 20 & 73.10 & $24(28)$ & 71.68 & $19(28)$ & 1.42 & .994 \\
\hline 21 & 51.48 & $2(25)$ & 50.90 & $22(25)$ & .58 & .089 \\
\hline 22 & 61.09 & $28(28)$ & 59.35 & $7(28)$ & 1.74 & -1.231 \\
\hline 23 & 62.07 & $28(28)$ & 60.26 & \begin{tabular}{l|l|}
16 & 28 \\
\end{tabular} & 1.81 & -.166 \\
\hline 24 & 55.36 & $30(30)$ & 53.72 & $11(30)$ & 1.64 & .116 \\
\hline 25 & 58.75 & $27(27)$ & 57.77 & $10(27)$ & .98 & -.309 \\
\hline 26 & 63.73 & $25(25)$ & 62.04 & $3(25)$ & 1.69 & .740 \\
\hline$M$ & 59.90 & & 58.83 & & 1.36 & \\
\hline SD & 6.95 & & 6.82 & & .47 & \\
\hline
\end{tabular}

Days of cycle numbered with day 1 as the first day of flow, day 2 as second day of cycle, etc. The total length of cycle is in parentheses.

$\star \star \quad B W$ change $=B W($ high $)-B W($ low $)$

*** (\%fat on day of high BW) - (\% fat on day of low BW) 
longitudinal effects on body composition of training and/or diet. In summary, with the adequate sample size and the controls maintained, the study has shown that weight during the five days preceding menstruation is significantly higher than the weight during the second half of the follicular stage (or the preovulatory weight). However, such weight changes do not appear to create significant changes in the components of body composition as measured with the hydrostatic weighing technique. The variability found in certain individuals emerged as an issue warranting further investigation. 
CHAPTER VI

CONCLUSION AND IMPLICATIONS FOR FUTURE RESEARCH

This study substantiated that there are significant changes in the $\mathrm{BW}$ of women corresponding to stages in the menstrual cycle. On the average the women in this study gained $.48 \mathrm{~kg}$. during the five-day period immediately preceding menstruation as compared to the latter half of the follicular phase or the phase immediately preceding ovulation. For these same blocks there were no significant differences in estimates of the components of $B C$ as measured with the HW technique. Therefore it is concluded that on the average:

(1) women experience weight gains preceding menstruation, and

(2) such weight gains are small and do not result in significant differences in the components of $B C$ by HW at these same times.

Future longitudinal research into the causes of the withinsubject variability is warranted as such information would be of particular interest in studies which explore the longitudinal effects of training and/or diet on body composition. Future longitudinal studies into this question should consider a number of changes in experimental design and/or methods. With weighing three times per week, only $43 \%$ of all daily weights were recorded, leaving $57 \%$ of BW 
scores missed, (or a $57 \%$ chance of missing a subject's peak weight). Increasing the number of BW trials would increase the chance of finding the low and/or high weight. Underwater weights at every BW trial lor at the high and low weights as in this study) would al so give further insight into the variability found for the components of body composition. RV measurements at every underwater weighing would provide more information into the variability that is associated with this parameter. As Rahn, Feen and Otis (1949) found that RV had a coefficient of variation three times of that for vital capacity for the same subjects, perhaps a different measure (vital capacity or functional residual capacity) would help to control the variability of these measures.

Further refinements in experimental design would include a control over food intake, either through a controlled diet or with food records. The environmental influences on weight gain might be eliminated in this way, but also may eliminate those gains due to cravings for salts or sugars which may be associated with the menstrual cycle (Thorn et al, 1938, Smith and Sauder, 1969). If food records were kept, plus the refinements in UW weighing procedures discussed above were followed, perhaps the variations in density, \%fat, fat weight, and fat-free weight could be better explained. 
BAKKER, H. K. and R. S. STRUIKENKAMP 1977 "Biological Variability and Lean Body Mass Estimates" Human Biology 49 (2): 187-202

BLAUSTEIN, Jeffrey K. and George N. WADE 1976 "Ovarian Influences on the Meal Patterns of Female Rats" Physiology and Behavior Vol. 17: pp 201-208

BROZEK, Josef and Austin HENSCHEL 1961 "Techniques for Measuring Body Composition" National Academy of Sciences, National Research Council, Washington D.C.

BROZEK, Josef, Ancel KEYES and Joseph ANDERSON 1963 "Densitometric Analysis of Body Composition: Revision of Some Quantificative Assumptions." Annals of the N.Y. Academy of Science, 110:112-140

BRUCE Joan and G. F. RUSSELL 1962 "Premenstrual Tension: A Study of Weight Changes and Balances of Water, Sodium and Potassium" The Lancet 2: 267-271

BUSKIRK, E. R. 1961 "Underwater Weighing and Body Density: A Review of Procedures in: Techniques for Measuring Body Composition. Ed Josef Brozek and Austin Henschel Washington, D.C., National Academy of Science pp 90-106

BYRD, Patricia J. and Tom R. THOMAS 1983 "Hydrostatic Weighing During Different Stages of the Menstrual Cycle", Research Quarterly, $54(3): 296-298$

CRAIG, Albert B. and Donald E. WARE 1967 "Effect of Immersion in Water on Vital Capacity and Residual Volume of the Lungs" Journal of Applied Physiology 23 (4): 423-25

CZAJA, John A. 1974 "Food Rejection by Female Rhesus Monkeys During the Menstrual Cycle and Early Pregnancy" Physiology and Behavior $14: 579-587$

CZAJA, John A. and Robert W. GOY 1975 "Ovarian Hormones and Food Intake in Female Guinea Pigs and Rhesus Monkeys" Hormones and Behavior $6: 329-349$

DALVIT, Stephanie P. 1981, "The effect of the Menstrual Cycle on Patterns of Food Intake" American Journal of Clinical Nutrition 34: $1811-1815$

EL MAHGOUB S. 1980 "Body Weight and Cycle Control of Injected Contraceptives" Journal of Reproductive Medicine, 24 (3): 119-26 
ERDLYI, G. J. 1976 "Effects of Exercise on the Menstrual Cycle" Physician and Sports Medicine, 4 (3): 79-83

GARLICK M. A. and E. M. BERNAUER 1968 "Exercise During the Menstrual Cycle: Variations in Physiological Baselines" Research Quarterly 39: 533-542

GARN, Stanley M. 1963 "Human Biology and Research in Body Composition" Annals of the N.Y. Academy of Science Vol. 110, Part II : $429-\overline{46}$

GAY, L. R. 1981 Educational Research Columbus, Ohio, Charles E. Merril1 Publishing Co.

GIRANDOLA, Robert N., Robert A. WISWELL, John G. MOHLER, Gary T. ROMERO and William S. BLAMES 1977 "Effects of Water Immersion on Lung Volumes: Implications for Body Composition Analysis" Journal of Applied Physiology 43 (3): 276-279

GIRANDOLA, Robert M., Robert A. WISWELL and Gary ROMERO 1977 "Body Composition Changes Resulting from Fluid Ingestion and Dehydration: Research Quarterly, 48 (2): 299-303

GOLDMAN, R. F. and E. R. BUSKIRK 1961 "Body Volume Measurement by Underwater Weighing: in Techniques for Measuring Body Composition Washington D. C., National Academy of Sciences Eds. Josef Brozek and Austin Henshel: 118-135

GOLDZIEHER, Joseph W., C. Brandon CHENAULT, I. B. WOUTERSZ, Bruce E. SCHNEIDER, and Paul R. HANSEN 1980 "Clinical Effects of Ethynal Estrogens Used on Bleeding Patterns, Weight and Blood Pressure" Contraception 22 (4): 360-381

GOOD, W. 1978 "Water Relations of the Ovarian Cycle" British Journal of Obstetrics and Gynecology vol. 85; 63-69

GUYTON, Arthur C. 1981 Textbook of Medical Physiology W. B. SAUNDERS, New York

HERVEY, Elizabeth and G. R. HERVEY 1967 "The Effects of Progesterone on Body Weight and Composition in the Rat" Journal of Endocrinology 37: 361-384

HIRATA, Kin-Itsu 1966 "Physique and Age of Tokyo 0lympic Champions" Journal of Sports Medicine and Physical Fitness Vol. 6, No. 4: pp 207-22

JACKSON, Andrew S. and Michael L. POLLOCK 1977 "Prediction Accuracy of Body Density, LBW and TBV Equations" Medicine and Science in Sports and Exercise 9 (4): 197-201 
JURKOWSKI, Janet E., Norman L. JONES, W. Christopher WALKER, Edward V. YOUNGLAE and John R. SUTTON 1978 "Ovarian Hormonal Response to Exercise" Journal of Applied Physiology 44: 109-14

KATCH, Frank 1967 "Apparent Body Density and Variability During Underwater Weighings" Research Quarterly 51 (1): 249-5

KATCH, Frank I. 1969 "Practice Curves in Hydrostatic Weighing" Medicine and Science in Sport 1 (4): 212-216

KATCH, Frank I., Ernest D. MICHAEL, and Steven M. HORVATH 1967 "Estimation of Body Volume by Underwater Weighing" Journal of Applied Physiology 23 (5): 811-813

KATCH, Frank I., and Victor L. KATCH 1980 "Measurement and Prediction Errors in Body Composition Assessment and the Search for the Perfect Prediction Equation" Research Quarterly 51 (1): 249-5

KATCH, Frank I. and William D. MCCARDLE 1973 "Simple Anthropometric Measurements in College Age Men and Women" Human Biology 45:445

KEYS, Ancel and Josef BROZEK 1953 "Body Fat in Adult Man" Physiological Reviews 33: 245-325

KIRK, Roger E. 1969 Procedures for Behavioural Sciences Belmont, California, Brooks/Cole Publishing Co.

LEIN, Allen 1979 The Cycling Female, San Francisco, W. H. FREEMAN and Company

LOHMAN, T. G. 1981 "Skinfolds and Body Density and Their Relation to Body Fatness" Human Biology 53 (2): 181-225

LOHMAN, T. G. 1982 "Body Composition Methodology in Sports Medicine" The Physician and Sports Medicine 10 (12): 46-58

NIE, Norman H. and C. HADLAI HULL 1981 SPSS Update 7-9 New York, N.Y., McGraw-Hill Book Company

NOFZIGER, Margaret 1976 A Cooperative Method of Natural Birth Control The Book PubTishing Co., Sumaer, Tennessee

NOVAK, Ladislav P. 1974 "Analysis of Body Compartments in Fitness Health and Work Capacity Ed. Leonard A. Larsen, New York, N.Y. MacMillan Publishing Co. 
RAHN, Hermann, Wallace O. FEEN and Arthur B. OTIS 1949 "Daily Variations in Vital Capacity, Residual Air, and Expiratory Reserve" Journal of Applied Physciology 1: 725-749

RATHBUN, Edith M., Nello PACE 1945 "The Determination of Total Body Fat by Means of the Body Specific Gravity" Journal of Biological Chemistry 158: 667-676

ROBINSON, Marion F. and Patricia E. WATSON 1965 "Weight Changes Due to the Menstrual Cycle" British Journal of Nutrition 19: 225-235

SINNING, Wayne E. 1977 "Body Composition Analysis by Body Densitometry" NAGWS Research Reports III pp 82-88

SIRI, W. E. 1961 "Body Composition from Fluid Spaces and Density: Analysis of Methods" in Techniques for Measuring Body Composition Washington, D.C., National Academy of Science Eds. Josef Brozek and Austin Henschel: 223-244

SMITH, Stuart L. and Cynthia SAUDER 1969 "Food Cravings, Depression, and Premenstrual Problems" Psychosomatic Medicine 31 (4): 218-287

SOLOMON, Susan J., Mindy DURZER, and Doris H. CALLOWAY 1982 "Menstrual Cycle and Basal Metabolic Rate in Women" American Journal of Clinical Nutrition 36: 611-616

STEVENSON, Lou A., Margaret A. KOLKA, and J.E. WILKERSON 1982 "Perceived Exertion and Anaerobic Threshold During the Menstrual Cycle" Medicine and Science in Sports and Exercise 14 (3): 218-222

THOMAS, TOm R. and Gil L. ETHERIDGE 1979 "Prolonged Exercise and Changes in Percent Fat Determination by Hydrostatic Weighing and Scintillation Counting" Research Quarterly Vol. 50, No. 4 pp $709-714$

THOMAS, Tom R, and Gil L. ETHERIDGE 1980 "Hydrostatic Weighing at Residual Volume and Functional Residual Capacity" Journal of Applied Physiology 49 (1): 157-159

THORN, George W., Katherine R. NELSON and Doris W. THORN 1938 "A Study of the Mechanism of Edema Associated With Menstruation" Endocrinology Vol. 22 (2): 155-163

URICCHIO, William A. editor 1973 Proceedings of a Research Conference on Natural Family Planning washington, D.C., The Human Life Foundation 
WELTMAN, Arthur and Victor KATCH 1981 "Comparison of Hydrostatic Weighing at Residual Volume and Total Lung Capacity" Medicine and Science in Sports and Exercise Vol. 13, No. $3: \frac{210-213}{213}$

WERDEIN, E. J. and L. H. KYLE 1960 "Estimation of the Constancy of the Fat-Free Body" Journal of Clinical Investigation 39: 626-629

WILLIAMS, Robert 1980 Textbook of Endocrinology New York, N.Y., W. B. Saunders

WILMORE, Jack H. 1969 "The Use of Actual, Predicted and Constant Residual Volumes in the Assessment of Body Composition by Underwater Weighing" Medicine and Science in Sports 1 (2): 87-90

WILMORE, Jack H. 1969 " A Simplified Method for Determination of Residual Lung Volume" Journal of Applied Physiology 27 (1): 96-102

WILMORE, Jack H. 1983 "Body Composition in Sport and Exercise: Direction for Further Research" Medicine and Science in Sports and Exercise 15 (1): pp 21-31

WILMORE, Jack H., Paul A. VODAK, Richard B. PARR, Robert N. GIRANDOLA, and John E. BILLING 1980 "Further Simplication of a Method for Determination of Residual Lung Volume" Medicine and Science in Sports and Exercise $12(3): 216-218$

WILMORE, Jack H. and Albert R. BEHNKE 1970 "Anthropometric Estimation of Body Density and Lean Body Weight in Young Women" American Journal of Clinical Nutrition Vol. 23 (3): 267-274 


\section{APPENDIX}

\section{DEFINITIONS OF TERMS AND SYMBOLS}

BODY WEIGHT (BW): The weight of the subject in kilograms.

DENSITY (D): The weight per unit volume of the body in $\mathrm{kg} . / \mathrm{L}$ (or $\mathrm{g} / \mathrm{ml})$.

FAT WEIGHT (FW): The weight of the body's fat in kilograms. FAT-FREE WEIGHT (FFW): The body weight minus the weight of body fat.

RESIDUAL VOLUME (RV): Volume of air remaining in the lungs at the end of maximal expiration.

PERCENT FAT (\%fat): Percent of the body attributed to fat 